\title{
An innovative option contract for allocating water in inter-basin transfers: the case of the Tagus-Segura Transfer in Spain
}

\begin{abstract}
The Tagus-Segura Transfer (TST), the largest water infrastructure in Spain, connects the Tagus basin's headwaters and the Segura basin, one of the most water-stressed areas in Europe. The need to increase the minimum environmental flows in the Tagus River and to meet new urban demands has lead to the redefinition of the TST's management rules, what will cause a reduction of transferable volumes to the Segura basin. After evaluating the effects of this change in the whole Tagus-Segura system, focusing on the availability of irrigation water in the Segura, the environmental flows in the Tagus and the economic impacts on both basins; we propose an innovative two-tranche option contract that could reduce the negative impacts of the modification of the Transfer's management rule, and represents an institutional innovation with respect to previous inter-basin water trading. We evaluate this contract with respect to spot and non-market scenarios. Results show that the proposed contract would reduce the impact of a change in the transfer's management rule on water availability in the recipient area.
\end{abstract}

Keywords: option contract, supply risks, Tagus-Segura Transfer, water markets

\section{Introduction}

One of the main objectives of water management is to deliver the required supply reliability levels and mitigate the social, economic and environmental consequences of droughts and floods. Water infrastructure and allocation rules mitigate climatic cycles but do not 
completely eliminate supply risks. Spot water markets facilitate the efficient allocation of this resource and have some supply risk reduction properties, but do not provide efficient risk allocation mechanisms per se, which exploit differences in risk tolerance and exposure (Calatrava and Garrido 2006; Rey et al., 2016).

Although the legal basis for water trading was approved in 1999, formal water markets barely functioned in Spain until 2006, when inter-basin trading was authorised during drought periods. Trading experiences have been limited and the existing market system presents important shortcomings (Garrido et al., 2013; Rey et al., 2014). After legislative changes in 2013, inter-basin water trading is permanently allowed, not only during drought periods. Although inter-basin water markets still require the approval of the Spanish Government, this amendment will have important consequences due to the huge potential for inter-basin water exchanges.

Climate change projections show an important decrease in water availability for all Spanish River basins, especially in southern Spain (Garrote et al., 2015), with significant expected economic impacts (Maestre-Valero et al., 2013). In such context, water option contracts could add flexibility and security to users and suppliers' operations (Kidson et al., 2013). Options are one type of derivative contract that give the holder the right (not the obligation) to buy or sell the underlying asset (Cui and Schreider 2009; Cheng et al., 2011). These contracts do not imply the transfer of ownership and therefore, the right-holders retain control of the water allotment should the option not be exercised (Gómez-Ramos and Garrido 2004; Leroux and Crase 2010). In the Spanish water market, option contracts have not been used, but there have been a couple of experiences of multi-annual contracts that 
resemble an option contract, and they have been extensively studied for the Spanish context (Gómez-Ramos and Garrido, 2004; Cubillo, 2010; Rey et al., 2016).

The Tagus-Segura Transfer (TST), the largest water infrastructure in Spain, connects the Tagus basin's headwaters and the Segura basin, one of the most water-stressed areas in Europe, covering a distance of more than $300 \mathrm{~km}$. As water scarcity in the Tagus basin is becoming a serious concern, a change in the TST management rules has already been agreed upon (CHT 2013), in the sense of making it more restrictive in the provision of water resources to the Segura basin during dry periods.

The aim of this paper is to evaluate the resulting impacts of the change in the TST management rules and the potential of inter-basin trading as a mechanism to reduce these impacts on the Segura basin. Specifically, we propose a novel water option contract between users in the Tagus and the Segura basins and evaluate it with respect to previous spot market experiences. This innovative two-tranche option contract would: a) minimise the impact of the new TST management rules on irrigation water availability in the Segura basin, without affecting environmental flows in the Tagus River; and b) reduce risk, increase stability and security in inter-basin water exchanges for both parties.

The paper is organised as follows: first, we present the case study. Second, we define the main features of the proposed option contract and present the other considered scenarios (spot market and no market). The fourth section describes the data and modelling framework, while the fifth presents the impact of different scenarios on the irrigators' water availability in the Segura basin and on the environmental flows in the Tagus River, together with the economic analysis. 


\section{Case study: The Tagus-Segura Transfer}

\subsection{Tagus-Segura Transfer}

The Segura basin is the most water scarce basin in Spain with a structural water deficit of 458 million $\mathrm{m}^{3} /$ year (CHS 2014). Usually, this deficit is covered by non-renewable groundwater pumping and deficit water application to crops, frequently under water stress conditions (Calatrava and Martínez-Granados 2012). The TST was projected in the 1970s to reduce this deficit by transferring water resources from the Upper Tagus basin to irrigation districts (IDs) and urban water suppliers in the Segura basin (Figure 1), being approved by law in 1979. At this point, it is important to clarify that the ordinary water transfers using the TST do not result from market exchanges but from water rights allocated to users in the Segura.

\section{HERE FIGURE 1}

The annual transferred volume depends on the water stock jointly stored in the interconnected Entrepeñas and Buendía reservoirs (E-B) in the Upper Tagus basin, with a storage capacity of 2,443 million $\mathrm{m}^{3}$. Prior to 1980 (when the TST started operating), the stock in E-B was above 1,500 million $\mathrm{m}^{3}$ for $70 \%$ of the months of the year (CHT 2011). Since 1980 the stored volume has experienced a sharp drop and the total volume hardly ever surpassed 1,500 million $\mathrm{m}^{3}$ (Figure 2). Fluctuations in the stored volume result in uncertainties about the annual volume to be transferred to the Segura basin. Designed to transfer 1,000 million $\mathrm{m}^{3} /$ year, in practice much less water volumes have been transferred with large inter-annual variations (Martínez-Granados et al., 2011). Average annual 
water transferred between 1979 and 2009 is 305 million $\mathrm{m}^{3}$ (205 for irrigation and 100 for domestic consumption).

\section{HERE FIGURE 2}

Water delivery to the Segura is based on certain transfer management rules that guarantee that the Tagus basin's demands are always met. Twice a year, the Ministry of Environment announces the maximum volume that can be transferred to the Segura basin during the following semester, based on the volume stored in E-B (Table 1). The maximum annual legally transferable volume is 600 million $\mathrm{m}^{3}$, an amount that has rarely been reached since the Aqueduct was built. When the monthly water stock in E-B is below a minimum threshold (Level 3), the responsibility of deciding over the transfer operations shifts from the Tagus's Basin Agency to the Council of Ministers. Therefore, there is some discretionary political power presiding over the inter-basin operations.

\section{HERE TABLE 1}

Since the beginning, some stakeholders from the Tagus basin have contested the TST operations (Hernandez-Mora and Del Moral, 2015). Their argument is that there is no water surplus in the basin, so water should remain there for the different economic activities, to meet urban demands and to maintain a good ecological status of the Tagus River. This opposition grows stronger during drought periods.

\subsection{Water availability risk in the Segura basin}

Farmers in the Segura basin that receive water from the Tagus basin face important risks due to water supply variability. In addition, when the transferred volume is low, irrigators' 
water volumes are the most affected as urban users have legal priority over irrigation (Figure 2).

The reduced water volumes transferred during drought periods forced water users in the Segura basin to draw on the water market to obtain enough resources for their activity. In 2005, the extreme drought situation in the Segura basin lead the Ministry of the Environment to authorize inter-basin trading using the TST infrastructure, an exceptional situation that lasted until 2009 (Garrido et al., 2013). Two major trading experiences took place during that period between IDs in the Tagus basin (sellers) and IDs and urban suppliers in the Segura basin (buyers, all of them beneficiaries of the TST) (Calatrava and Gómez-Ramos 2009; Hernandez-Mora and Del Moral, 2015).

First, the MCT, the major urban water supplier in the Segura basin, signed three consecutive annual agreements with farmers in the Canal de las Aves ID to transfer a total of 108,5 million $\mathrm{m}^{3}$ during 2006, 2007 and 2008 at an average price of $0.28 € / \mathrm{m}^{3}$. Second the SCRATS (an association representing all IDs served by the TST) signed a contract, renewed during four years, with the Canal de Estremera ID in the Tagus basin to transfer 31.05 million $\mathrm{m}^{3} /$ year at an average price of $0.186 € / \mathrm{m}^{3}$ (prices are paid in origin and do not include transportation costs).

As these parties had already arranged water exchanges in four consecutive years, we conjecture that they might be interested in signing a water option contract under the new legislation (in which inter-basin trading is not restricted to drought periods) due to the institutional stability it would provide. 


\subsection{Water productivity values}

Considerable differences in water productivity between the selling and the buying areas to cover the transaction, transportation and environmental costs are crucial for water trading to take place. This is the case between the Tagus and Segura basins. For instance, the apparent productivity of irrigation water in Madrid (Tagus basin) is $0.6 € / \mathrm{m}^{3}$, while in Murcia (Segura basin) it is $3.4 € / \mathrm{m}^{3}$ (Gil et al. 2009). Similarly, the value of water presents significant differences. In the Tagus basin, the average and marginal values of water are $0.06 € / \mathrm{m}^{3}$ and $0.29 € / \mathrm{m}^{3}$, respectively (Calatrava 2007); whereas in the irrigated areas served by the TST the average and marginal values of water are $0.69 € / \mathrm{m}^{3}$ and $0.95 € / \mathrm{m}^{3}$, respectively $^{1}$ (Calatrava and Martínez-Granados 2012). Such difference favours the arrangements of inter-basin water exchanges.

\section{Scenario description}

The scenarios considered in our analysis result from the combination of both the traditional and new TST management rules and different water trading alternatives, resulting in 5 different scenarios:

- $\quad$ Scenario 1a: traditional TST management rule without water trading;

- $\quad$ Scenario 1b: traditional TST management rule with spot water purchases in drought periods;

- $\quad$ Scenario 2a: new TST management rules without water trading;

\footnotetext{
${ }^{1}$ The high water values in the Segura are, in part, due to the concentration of horticultural crops and greenhouses, and also to the widespread modernization of irrigation systems (Calatrava and MartínezGranados 2012). The agricultural sector that depends on the transferred volumes from the Tagus basin generates $1268 €$ million to the GDP of the Segura basin (PwC 2013). The cancellation of the TST would lead to a reduction of the GDP close to 7.1\% (Sancho 2008).
} 
- Scenario 2b: new TST management rule with spot water purchases in drought periods;

- $\quad$ Scenario 2c: new TST management rule with the proposed option contract (different parameterizations).

\subsection{Tagus-Segura Transfer management rules}

The traditional management rule of the TST can be conceptually defined as:

$$
V_{t_{1}}=f\left(\tilde{S}_{t}\right)
$$

$V_{t_{1}}$ is the annual transferred volume (in million $\mathrm{m}^{3}$ ) to the Segura basin and $\tilde{S}_{t}$ is a stochastic function of the water storage on January $1^{\text {st }}$ in E-B reservoirs. Function $f($.$) has$ been statistically fitted using records of TST operations from the three previous decades.

We also define the new management rule as $V_{t_{2}}=g\left(\tilde{S}_{t}\right)$, which is similarly shaped to $f($.$) but with different parameters, resulting in different probability density functions for$ $V_{t_{1}}$ and $V_{t_{2}}$. This is a mathematical representation of the agreement reached in 2013 to change the TST management rule.

\subsection{Water market scenarios}

We define two different water market scenarios: a spot market, similar to the inter-basin trading activity that took place between 2005 and 2008, and the proposed water option contract.

The water volume exchanged through the spot market is modelled as follows: 


$$
\tilde{V}_{s p o t}=\tilde{p} V_{s}
$$

$\tilde{V}_{\text {spot }}$ is the stochastic purchased volume if the hydrological conditions prevailing during the 2005-2008 drought period are met $^{2}$, which occurs with probability $p$; $\tilde{p}$ is a binomial distribution $(0,1)$ and $V_{s}$ is equivalent to 31.05 million $\mathrm{m}^{3}$ (the annual volume purchased by irrigators in the Segura basin during the 2005-2008 drought period). Although there are not sufficient observations to fit a binomial distribution, we assume that if spot trading activity took place under some circumstances in the past it will also occur in the future under the same conditions.

The other market scenario is the water option contract. We propose an original multi-annual option contract, which would provide institutional stability and security and thus would be potentially interesting for both basins. The agreement is multiannual but the decision to acquire the water should be annual. It is modelled as follows:

$$
\tilde{V}_{\text {option }}=\tilde{q} 31.05+(1-\tilde{q}) H\left(\Delta \tilde{I}_{I-M}\right)
$$

$\tilde{V}_{\text {option }}$ is the water volume purchased through the option contract; $\tilde{q}$ is a binomial variable $(0,1) ; \Delta \tilde{I}_{I-M}$ is the stochastic accumulated inflows during the first five months of the year in E-B; and $H($.$) is a function that yields the proportion of \Delta \tilde{I}_{I-M}$ that can be purchased under this scheme.

The proposed option contract has two different components with different purposes. The first tranche is intended to protect Segura's irrigators when the stock level in E-B is

\footnotetext{
${ }^{2}$ Water stock in the E-B reservoir $<550$ million $\mathrm{m}^{3}$.
} 
low by purchasing water from the Tagus through the TST. The second tranche would allow irrigators in the Segura basin to have access to more water when the stock level in the E-B reservoirs is high, as a compensation for the change in the TST management rules.

Each tranche has a different water seller involved. The first one $(\tilde{q}=1)$ represents a contract between irrigators in the Segura basin (buyer) and irrigators in the Tagus basin (seller). The trigger associated to this part of the contract would be a minimum stock level in E-B. Therefore, when the stock level is below this limit, irrigators in the Segura can purchase the corresponding water volume. Based on previous exchanges between these parties, we assume that the maximum volume that they would have access to with this part of the agreement is 31.05 million $\mathrm{m}^{3}$. This part of the contract intends to integrate past spot market experiences in a more reliable and secure system.

The second tranche $(\tilde{q}=0)$ represents an agreement between irrigators in the Segura basin and the Tagus Basin Agency and could only be accessed when the water stock in E-B is higher than the established trigger, allowing the buyer to purchase a proportion $H$ of the accumulated water inflows in the reservoir between January and May.

\section{Empirical model and parameterization}

Three different issues have been analyzed for each scenario: i) irrigators' water availability in the Segura basin (referring only to resources from the Tagus basin); ii) remaining stock in the Tagus basin headwaters reserves; and iii) economic impact on the whole TagusSegura system. Using Monte-Carlo simulation techniques we have obtained the probability distribution functions (PDFs) of these three variables for each scenario. By comparing these PDFs, we can compare the impacts of the TST management rules and the different water 
trading mechanisms on water availability and on the economic performance of the whole system.

\subsection{Water availability for irrigators in the Segura basin}

\subsubsection{Volumes transferred under each management rule}

For the definition of water availability under the traditional rule (previously explained in section 3.1), a regression model describing the annual transferred volume $\left(V_{t_{1}}\right)$ has been fitted. This variable cannot be treated as stochastic due to the existence of the TST's management rule (Table 1). A regression has been performed following this expression:

$$
V_{t_{1}}=k+a S_{t}+b D+c Y+d Y^{2}+\varepsilon_{t}
$$

$V_{t_{1}}$ : Annual volume transferred to the Segura basin $\left(\right.$ million $\left.\mathrm{m}^{3}\right) ; S_{t}$ : Water stock at the beginning of the year in E-B (million $\left.\mathrm{m}^{3}\right) ; D$ : Dummy variable $(0$ when the stock in January is below 1000 million $\mathrm{m}^{3} ; 1$ otherwise); $Y$ : Number of the year in the database $(1, \ldots, 20) ; \varepsilon$ : Error term $\left(\varepsilon \sim N\left(0, \sigma_{s}\right)\right)$. We have added a time variable $(Y)$ in both linear and quadratic terms because in previous and simpler specifications of the fitted model we observed that the error terms followed a quadratic pattern over time.

\section{HERE TABLE 2}

There are significant pressures to increase the minimum river flow, measured in Talavera de la Reina (downstream of Madrid, Tagus Basin), and currently set at $6 \mathrm{~m}^{3} / \mathrm{s}$ (CHT 2013). To achieve this, a higher stock level ('remaining stock') in E-B is required. 
We simulate a change from the traditional management rule, $V_{t_{1}}$, to the new management rule, $V_{t_{2}}$, that would allow maintaining higher water stocks in E-B. From the estimated function $V_{t_{1}}$ (Table 2), we derive function $V_{t_{2}}$, which has different curvature and parameters and is more restrictive in terms of the minimum stock level in E-B required to transfer a certain amount of water. The new TST management rule is thus as follows:

$$
V_{t_{2}}=-432+0.00037 S_{t}^{2}+1.078 S_{t}-1.68 Y^{2}+45.7 Y+\varepsilon
$$

In Figure 3, both management rules are depicted. The transferred volumes under the new rule would be lower when the stock in E-B is low. Neither the new nor the traditional rule permit transferred volumes greater than 600 million $\mathrm{m}^{3}$ (400 million $\mathrm{m}^{3}$ for irrigation).

\section{HERE FIGURE 3}

The water volume available for irrigators in the Segura basin under these scenarios (1a and $2 \mathrm{a}$ ) would be:

$$
\tilde{V}_{1 \alpha}=\min \left[f\left(\tilde{S}_{t}\right), 400\right] \quad \text { or } \quad \widetilde{V}_{2 a}=\min \left[g\left(\tilde{S}_{t}\right), 400\right]
$$

depending on whether the traditional or the proposed alternative management rule prevails.

\subsubsection{Water availability with spot purchases}

This scenario has been defined based on the water trading activity that took place during the previous drought period (see section 2.2), as follows:

$$
\tilde{V}_{t b}=\min \left[\left(V_{t}+\tilde{p} V_{s}\right), 400\right]
$$


$\tilde{V}_{t b}$ represents irrigators' water availability from the TST in the Segura basin; $V_{t}$ is the water transferred through the TST; $\tilde{p}$ is a binomial variable that takes the value 0 when the stock in E-B is higher than 550 million $\mathrm{m}^{3}$ and 1 otherwise. $V_{s}$ is the purchased volume (always 31.05 million $\mathrm{m}^{3}$ ).

\subsubsection{Water availability with the option contract}

The proposed option contract is defined as follows:

$$
\left.\tilde{V}_{2 c}=\min \left[V_{t_{2}}+\tilde{q} 31.05+(1-\tilde{q}) H_{i, j}\left(\Delta \tilde{I}_{J-M}\right)\right), 400\right]
$$

$V_{t_{z}}$ is the annual transferred volume based on the new TST management rule; $\tilde{q}$ is a binomial variable (equals to 1 when the stock level in E-B is below 550 million $\mathrm{m}^{3}$; zero otherwise). $H_{i, j}(\cdot)$ is the transformation function that defines the proportion of the increase of water inflows in the E-B reservoirs $\left(\Delta \tilde{I}_{J-M}\right)$ between January and May ${ }^{3}$, to which the option holder would have access to when the stock in E-B is higher than 550 million $\mathrm{m}^{3}$.

The contract is designed to protect irrigators' water availability in the Segura basin from the impacts of the change in the TST management rules. As this change attempts to improve the ecological status of the Tagus River, the option contract should not reduce its river flow. Therefore, when the stock level in the E-B is below 550 million $\mathrm{m}^{3}$, the buyer only has access to the first part of the contract (31.05 million $\left.\mathrm{m}^{3}\right)$. As this part of the agreement is between irrigators in each basin, it would not entail extra water consumption

\footnotetext{
${ }^{3}$ The inflows during these months are taken into account for the option contract model as the buyer has to decide whether to purchase the water or not at the end of May.
} 
and the positive impacts of the new management rule on environmental flows would not be impaired by this water transaction.

When the stock level is higher than 550 million $\mathrm{m}^{3}$, the second part of the contract would allow the buyer to access to a proportion of the accumulated inflows in the reservoir during the first five months of the year. If the option holder buys that water volume, the final stock in E-B will be reduced, as it is an extra consumption of water. However, with the change in the management rule, environmental flows will be guaranteed. This second part of the agreement would act as compensation to the TST beneficiaries for the change in the Transfer management rule.

Function $H_{i, j}($.$) takes different values depending on the total volume stored in E-B$ at the beginning of the year $(i)$ and on water inflows between January and May $(j)$. Some $H_{i, j}($.$) will be more restrictive in the proportion of the water inflows that the buyer could$ purchase. Different versions of this scheme could be proposed and analysed simply by changing these proportions. Higher proportions benefit the buyer but reduce storage levels in the E-B reservoirs. As an example, we have selected three different levels $(\mathrm{H} 1, \mathrm{H} 2, \mathrm{H} 3)$ of $H_{i, j}$, in order to evaluate their impact on the studied variables.

\section{HERE TABLE 3}

For the analysis of irrigators' water availability in the Segura basin (taking into account only water resources from the Tagus basin), the following data have been collected: monthly water inflows and stored volumes in E-B (1958-2011, in million $\mathrm{m}^{3}$ ), 
monthly transferred volumes to the Segura basin (1987-2011) and monthly water consumption from the TST by irrigators and municipalities (2000-2010).

\subsection{Water availability in the Tagus basin}

The following expression illustrates the effect of each scenario on the water stock level in the E-B reservoir and therefore, the volume that determines the Tagus River water flow:

$$
\tilde{S}_{t}=\tilde{S}_{t}+\Delta \tilde{I}_{J-D}-\tilde{V}_{x}-\tilde{U}_{t}
$$

$\tilde{S}_{\theta}$ is the stock in E-B on December $31^{\text {st }} ; \tilde{S}_{t}$ is the stock at the beginning of the year $^{4} ; \Delta \tilde{I}_{J-D}$ represents the annual water inflows during the year ${ }^{5} ; \tilde{V}_{x}$ is the transferred volume for irrigators in the Segura basin for each scenario; $\widetilde{U}_{t}$ is the annual transferred volume to urban suppliers in the Segura basin ${ }^{6}$. The remaining stock $\left(\tilde{S}_{e}\right)$ is meant to meet all water demands in the Tagus basin, including maintaining environmental flows. The larger the remaining volume is, the larger the river flows that can be granted will be.

\subsection{Economic valuation}

To estimate the economic impact of the proposed scenarios, we have estimated the economic value of transferred/sold water from the Tagus to the Segura basin and defined

\footnotetext{
${ }^{4} \xi_{t}$ : Discrete function fitted using historical data (1991-2010).

${ }^{5} \Delta I_{I-D}$ : Follows an Inverse Gauss pdf (p value: 0.6444). Distribution function fitted using historical data (1991-2010)

${ }^{6} \widetilde{U}_{t}$ : Follows an extreme value pdf (p value: 0.7358 ). Distribution function fitted using historical data (19872010).
} 
the positive and negative economic factors for each basin in scenario (Table 4). Their unitary values have been obtained from the existing literature in Spain. The Tagus basin receives the transfer fees (net of transportation costs) for the water transferred to the Segura, as a legal compensation to the areas-of-origin. On the other hand, the Tagus basin would incur in several opportunity costs related to that transferred (or sold) volumes, as a consequence of non-generated hydropower, foregone farm profit and environmental impacts. It is important to clarify that only those transferred volumes that come from ID water allotments (i.e., spot purchases and the first tranche of the option contract) result in an economic loss for the Tagus basin, as they would have been used for irrigation in the areas-of-origin. This economic impact has an associated multiplier effect that is also accounted for. In the recipient area, the transferred water volume would have a positive impact, including a multiplier effect on its economy. On the contrary, they have to pay the agreed price for each water source.

\section{HERE TABLE 4}

For the Tagus basin, the economic opportunity cost for each scenario has been calculated using water value curves obtained from a non-linear mathematical programming model, developed by Calatrava (2007) for the Tagus River Basin Authority, that simulates the economic use of irrigation water. The economic value of the transferred/sold water to the Segura basin has been computed using a non-linear mathematical programming model that simulates the economic use of water for irrigation in the basin (Martínez-Granados et al. 2011; Calatrava and Martínez-Granados 2012). 
For each scenario, the net benefit from the transferred/sold water volumes in the whole Tagus-Segura system has been calculated, taking into account all the abovementioned positive and negative factors in each basin, as follows:

$$
N B\left(\tilde{V}_{i}\right)=B\left(\tilde{V}_{i}\right)-C\left(\tilde{V}_{i}\right)
$$

$B$ are the benefits derived from the transferred volume; $C$ are the total costs; $\widetilde{V}_{2}$ is the water volume transferred/sold to irrigators in the Segura basin under scenario $i$. Obviously, a water transfer to another basin may have a negative impact on the area-of-origin. However, if the positive impact of this water transfer on the recipient area is higher, the overall welfare will be improved.

\section{Results and discussion}

\subsection{Water availability under the different scenarios}

During the last decade, irrigators in the Segura basin have relied on water markets to reduce the risk of not getting enough water from the Tagus basin (see Section 2.2). Figure 4 represents the effect of this market activity on irrigators' water availability in the Segura basin. The spot market reduces the risk on the left side of the distribution, allowing irrigators to get more water during drought periods.

\section{HERE FIGURE 4}

Under the new TST management rule (Eq.5), the transferred water volume for irrigators in the Segura basin would be reduced. Figure 5 shows this reduction if the management rule changes to a more restrictive one (from line 1a to line 2a). 
The proposed option contract offers a mechanism for offsetting this negative impact on water availability. With the first part of the contract, which entitles them to purchase water when the stock in E-B is low, this reduction is compensated. With the second part, based on $H\left(\Delta \tilde{I}_{J-M}\right)$, they have access to more water as E-B stock grows. Depending on the proportion of the accumulated inflows that irrigators in the Segura basin have access to $(\mathrm{H} 1, \mathrm{H} 2, \mathrm{H} 3)$, the impact of the change of the TST management rule would be reduced in a different magnitude. Scenario $2 \mathrm{c}$ would represent an improvement with respect to the water availability under the traditional rule, increasing the probability of obtaining 400 million $\mathrm{m}^{3}$ from the Tagus basin (from $3.7 \%$ to $9 \%$ for $\mathrm{H} 3$ ).

\section{HERE FIGURE 5}

The probability of not receiving any water from the Tagus basin increases under the new management rule, as more stock in E-B is required to transfer a certain amount of water. Therefore, irrigators in the Segura basin would receive less water when the stock level in E-B is low, allowing for a better and faster recovery of the water stock in the Upper Tagus basin. In these years, they could have access to the first part of the option contract and purchase 31.05 million $\mathrm{m}^{3}$ from an ID in the Tagus basin. When the stock in E-B is low, irrigators in the Segura basin would have access to the same water volume both with spot purchases and with the option contract, which is why the values of p5 and p10 are the same for both cases (see Table 5). 


\subsection{Remaining stock in $E-B$ reservoir}

Another important aspect of the proposed contract is its effect on the remaining water stock in E-B (Figure 6), and consequently on the environmental flows in the Tagus River. With the new management rule, that reduces the transferred volumes, the available stock in E-B would be higher, allowing the increase of environmental flows in the middle Tagus.

\section{HERE FIGURE 6}

The remaining stock in dry years (lower percentiles' values) is higher under the new rule with the option contract (even for H3) than under the traditional management rule. For higher percentiles, the stock differences are very small in relative terms (Table 5).

With the new management rule and the option contract, the left tail of the PDF of the stock in $\mathrm{E}-\mathrm{B}$ is higher (close to 50 million $\mathrm{m}^{3}$ higher in percentile $1 \%$ ), improving the hydrological status of the reservoir in critical years and allowing the maintenance of environmental flows. However, with the proposed scheme, in years when the stock in E-B is high, the holder could benefit from this situation, having access to a greater water volume.

\subsection{Economic analysis}

The economic value of the impacts identified for each basin and considered scenarios (see section 4.3), has been calculated for the whole Tagus-Segura system, taking into account the water volumes transferred to irrigators in the Segura basin under each scenario. Figure 7 shows the PDFs of the economic value for the whole system (considering both basins). 


\section{HERE FIGURE 7}

As shown in Figure 7, the Tagus-Segura Transfer generates important net economic benefits, mainly due to high-productive agriculture of the recipient area. A change in the TST management rules will lead to a negative impact in this Tagus-Segura system, which has been estimated on average at nearly $€ 200$ million. Both the spot purchases scenario and the option contract scenario reduce this negative impact. Moreover, results clearly show that the proposed option contract would be more beneficial for the Tagus-Segura system than a spot water market such as the currently existing one.

For P65 and higher percentiles (Table 5), the net benefit values from the option contract (H1) under the new management rule are slightly higher than the ones obtained for the traditional rule scenario. If higher $\mathrm{H}$ values of the option contract are considered, the net benefit under this scenario would be even higher than the ones obtained under the traditional management rule.

\section{HERE TABLE 5}

\section{Conclusions}

Water users in Mediterranean regions suffer considerable water supply risks. The TagusSegura Transfer has alleviated water scarcity in the Segura basin, but its water deliveries have economic and environmental effects in both the recipient basin and the area-of-origin. It operates under a management rule that depends on stochastic hydrological variables, but also on political discretionary decisions. 
Either because of the need to increase minimum environmental flows in the Middle Tagus or because of reduced run-off caused by climate change, or both, a redefinition of the management rules governing the TST had to be implemented. This change implies a reduction in the transferable volumes, especially in dry periods.

A water option contract similar to the one proposed here would reduce the negative impacts of the change in the management rule on both water availability and risk exposure of the transfer's beneficiaries. When the stock level in E-B is high, the option contract would allow irrigators in the Segura basin to access to even more water than with the traditional rule. When transferred water volumes are reduced, users in the Segura could rely on the first tranche of the contract and on other more costly but also more secure water sources, such as desalination.

The change in the management rule would increase the currently low environmental flows in the Tagus basin and meet the increasing demands. With the proposed option contract both objectives could be met, striking a more balanced equilibrium between environmental and irrigators' interests. Parameters in function $H($.$) , that determine the$ proportion of the water inflows that the buyer has access to, should be carefully chosen in order to meet these goals. In this paper, we have modelled three different $\mathrm{H}$ levels, somewhat arbitrarily set, to meet the general option contract requirement: acceptability by both sellers and buyers and by the Tagus basin's stakeholders.

The TST has an enormous importance for the economy in the recipient area, one of the most productive agricultural regions in Spain. A $10 \%$ reduction in transferred water volumes would cause a $1 \%$ reduction in the Segura basin's agricultural production in the 
short term and a $4 \%$ reduction in the long term $(\mathrm{PwC}, 2013)$. As our results show, a change in the TST management rule would have considerable economic impacts for the TagusSegura system, what should be taken into account when deciding the future of the most important water transfer in Spain.

As domestic uses have priority over irrigation, urban suppliers in the Segura basin face a smaller risk. However, as they depend on the resources from the TST, they are also affected when the transferred water is not sufficient to cover urban demands. Therefore, a water option contract like the one proposed here could be useful for them.

The restriction of inter-basin trading activity to drought periods did not encourage the development of more stable and sophisticated trading mechanisms. Under the new legislation, in which inter-basin trading can be authorised in all circumstances, option contracts could provide stability to both parties.

\section{References}

Calatrava J (2007) Valoración Económica del Uso Agrario del Agua en el Regadío de la Cuenca del Tajo. Technical report for the contract 03.805.010/0411, Confederación Hidrográfica del Tajo, Madrid

Calatrava J, Garrido A (2006) Difficulties in Adopting Formal Water Trading Rules within User's Associations. J Econ Issues XL (1): 27-44

Calatrava J, Gómez-Ramos A (2009) El papel de los mercados de agua como instrumento de asignación de recursos hídricos en el regadío español. In: Gómez-Limón JA, 
Calatrava J, Garrido A, Sáez FJ and Xabadia A (eds) La economía del agua de riego en España. Fundación Cajamar, Almería, pp 295- 319

Calatrava J, Martínez-Granados D (2012) El valor de uso del agua en el regadío de la cuenca del Segura y en las zonas regables del trasvase Tajo-Segura. Economía Agraria y Recursos Naturales 12(1): 5-32

Cheng W-Ch, Hsu N-S, Cheng W-M, Yeh W-G (2011) Optimization of European Call Options considering physical delivery network and reservoir operation rules. Water Resour Res 47, W10501

CHT (2008) Plan Especial de Sequía de la Cuenca Hidrográfica del Tajo, Confederación Hidrográfica del Tajo, Madrid

CHT (2011) Memoria Anual de la Confederación Hidrográfica del Tajo, Confederación Hidrográfica del Tajo, Madrid

CHS (2014) Plan Hidrológico de la Cuenca del Segura 2009-2015. Confederación Hidrográfica del Segura, Murcia

CHT (2013) Propuesta de proyecto de Plan hidrológico de cuenca de la parte española de la Demarcación Hidrográfica del Tajo. Confederación Hidrográfica del Tajo, Madrid

Cubillo F (2010) Looking for efficiency through integrated water management between agriculture and urban uses (Review). Water Sci Technol 10 (4): 584-590

Cui J, Schreider S (2009) Modelling of pricing and market impacts for water options. J Hydrol 371: 31-41

Elorrieta JI, Castellano E, Martinez de Anguita P, Pellitero M, Rey C (2003) Establecimiento de un precio óptimo ambiental y social para el agua de riego 
mediante la internalización de los costes ambientales y el uso de matrices de contabilidad. Aplicación a la Comunidad Foral de Navarra. Economía Agraria y de los Recursos Naturales 3: 139-166

Garrido A, Rey D, Calatrava J (2013) Water trading in Spain. In: De Stefano L and Llamas M R (eds) Water, Agriculture and the Environment in Spain: can we square the circle? Botín Foundation, CRC Press, pp 205-216

Garrote L, Iglesias A, Granados A, Mediero L, Martin-Carrasco F (2015) Quantitative Assessment of Climate Change Vulnerability of Irrigation Demands in Mediterranean Europe. Water Resour Manag 29: 325-338.

Gil M, Garrido A, Gómez-Ramos A (2009) Análisis de la productividad de la tierra y del agua en el regadío español. In: Gómez-Limón J.A., Calatrava J., Garrido A., Sáez F.J., and Xabadia A. (eds) La economía del agua de riego en España, Fundación Cajamar, Almería, pp 95-114

Gómez-Ramos A, Garrido A (2004) Formal risk-transfer mechanisms for allocating uncertain water resources: The case of option contracts. Water Resources Research 40, W12302

Hardy L, Garrido A (2010) Análisis y evaluación de las relaciones entre el agua y la energía en España. Papeles de Agua Virtual 6, Botin Foundation, Madrid

Hernández-Mora N, Del Moral L (2015) Developing markets for water reallocation: Revisiting the experience of Spanish water mercantilización. Geoforum 62:143-155. 
Kidson R, Haddad B, Zheng H, Kasower S and Raucher R (2013). Optimising reliability: portfolio modeling of contract types for retail water providers, Water Resour Manag 27: $3209-3225$

Leroux A, Crase L (2010) Advancing water trade: a preliminary investigation of urban irrigation options contracts in the Ovens Basin, Victoria, Australia. Economic Papers: A journal of Applied Economics and Policy 29: 251-266.

Maestre-Valero JF, Martínez-Granados D, Martínez-Álvarez V, Calatrava J (2013). SocioEconomic Impact of Evaporation Losses from Reservoirs Under Past, Current and Future Water Availability Scenarios in the Semi-Arid Segura Basin. Water Resour Manag 27:1411-1426

Martínez-Granados D, Maestre-Valero JF, Calatrava J and Martínez-Alvarez V (2011) The economic impact of water evaporation losses from water reservoirs in the Segura basin, SE Spain. Water Resour Manag 25: 3153-3175

MMA (2000) Plan Hidrológico Nacional, Ministerio de Medio Ambiente, Madrid

PwC (2013) Impacto económico del trasvase Tajo-Segura. PricewaterhouseCoopers.

Rey D, Calatrava J, Garrido A (2016) Optimization of water procurement decisions in an irrigation district: the role of option contracts. Australian Journal of Agricultural and Resource Economics, DOI: 10.1111/1467-8489.12110.

Rey D, Garrido A and Calatrava J (2014) Water Markets in Spain: Meeting Twenty-First Century Challenges with Twentieth Century Regulations. In: Easter K.W. and Huang Q. (eds.) Water Markets for the 21st. Century: What Have We Learned? Springer, Dordrecht, The Netherlands; pp. 127-147. 
San Martín E (2011) Un análisis económico de los trasvases de agua intercuencas: el trasvase Tajo-Segura, Thesis, UNED, Madrid

Sancho I (2008). El Trasvase Tajo-Segura: debate, impacto y propuestas. Universidad de Murcia, Murcia 
Fig. 1 Location of the Tagus and Segura basins and the Tagus-Segura Aqueduct. Source: Adapted from www.iagua.es

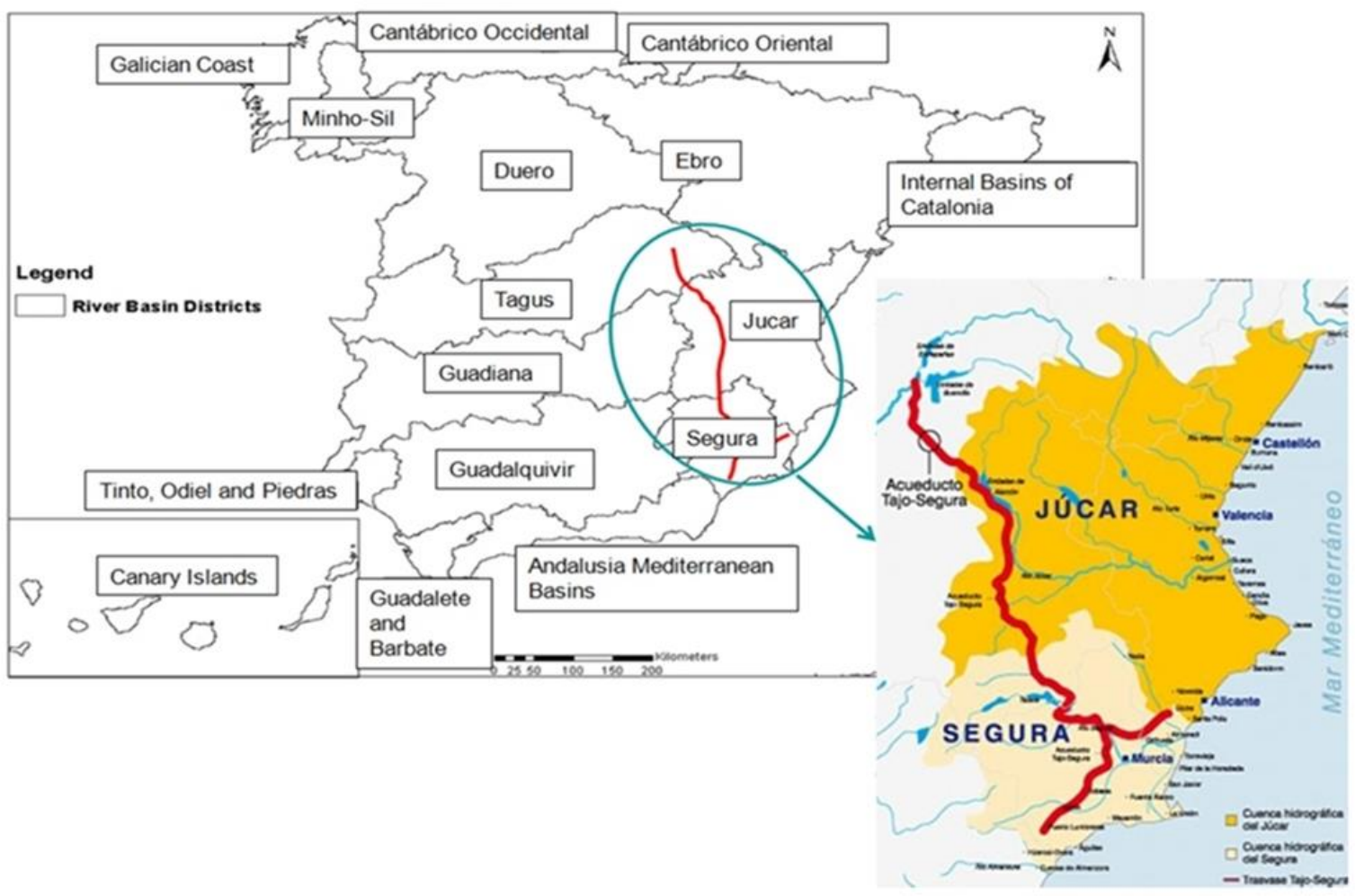


Fig. 2 Annual stored volume in Entrepeñas-Buendía (blue line, right axis) and volumes transferred for irrigators and urban suppliers through the Tagus-Segura Transfer, 19792011(million $\mathrm{m}^{3}$, left axis). Source: (CHT 2011) and San Martín (2011)

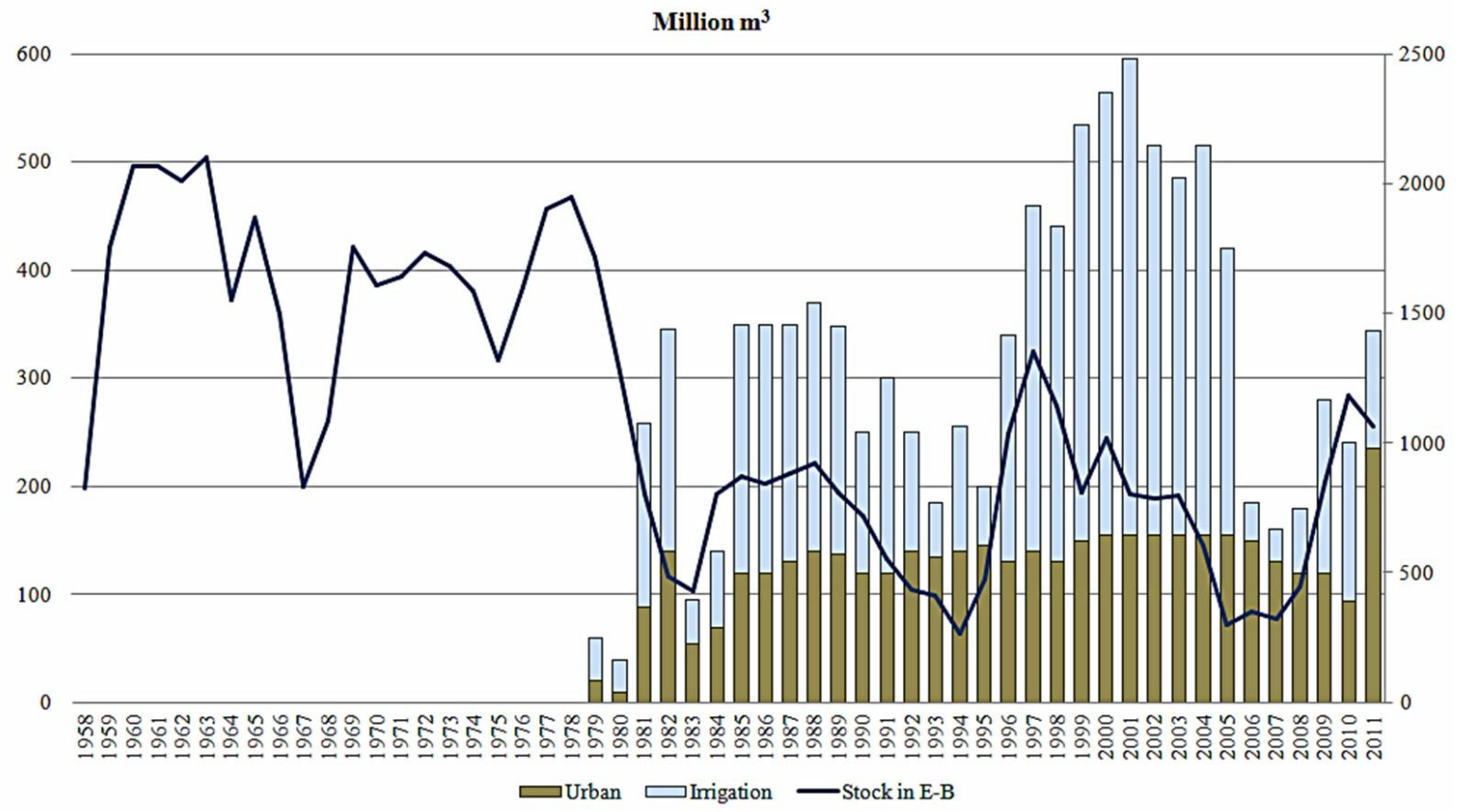


Fig. 3 Traditional and new management rules for the Tagus-Segura Transfer

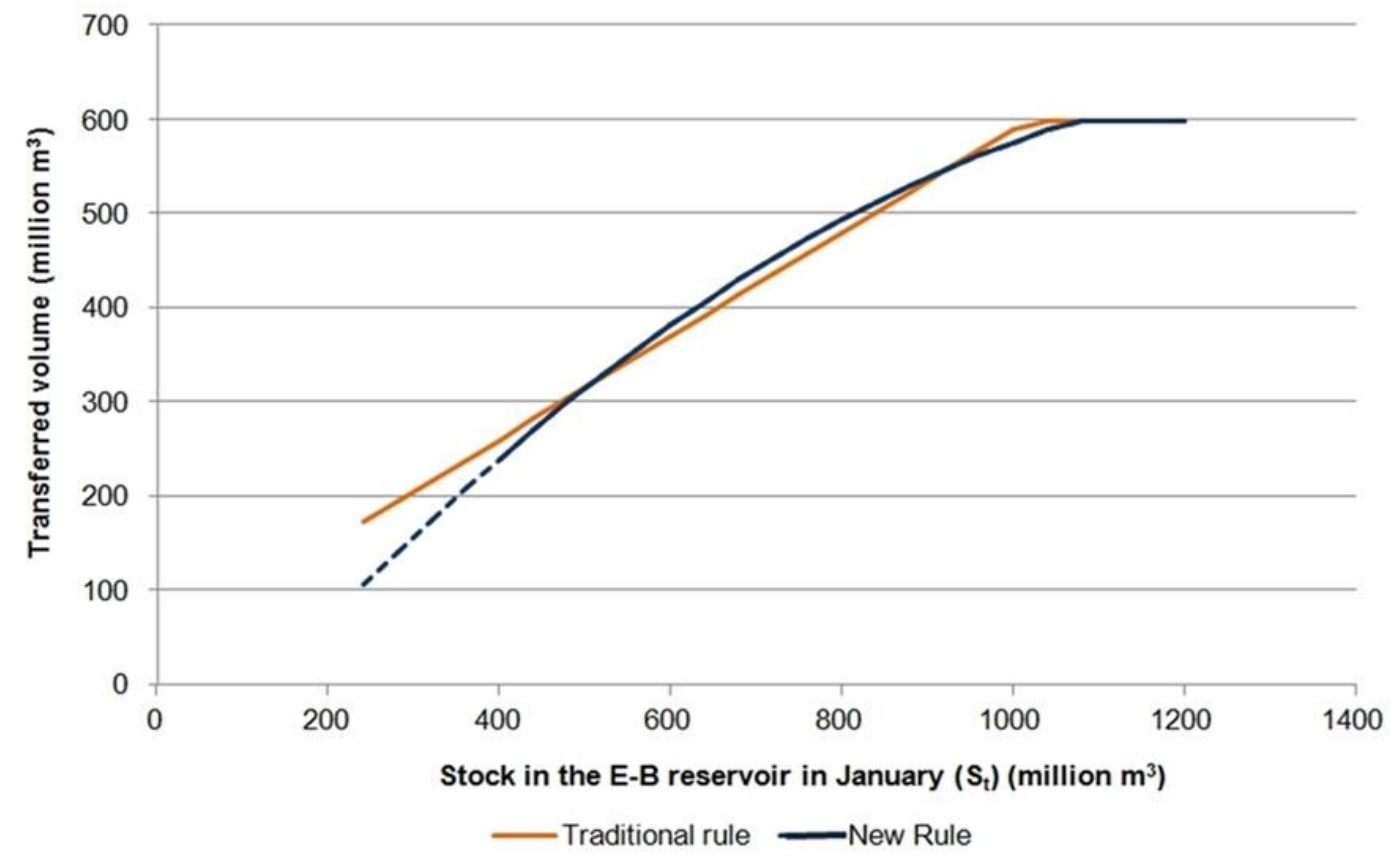


Fig. 4 Cumulative probability curves representing the water availability (million $\mathrm{m}^{3}$ ) for irrigators in the Segura basin

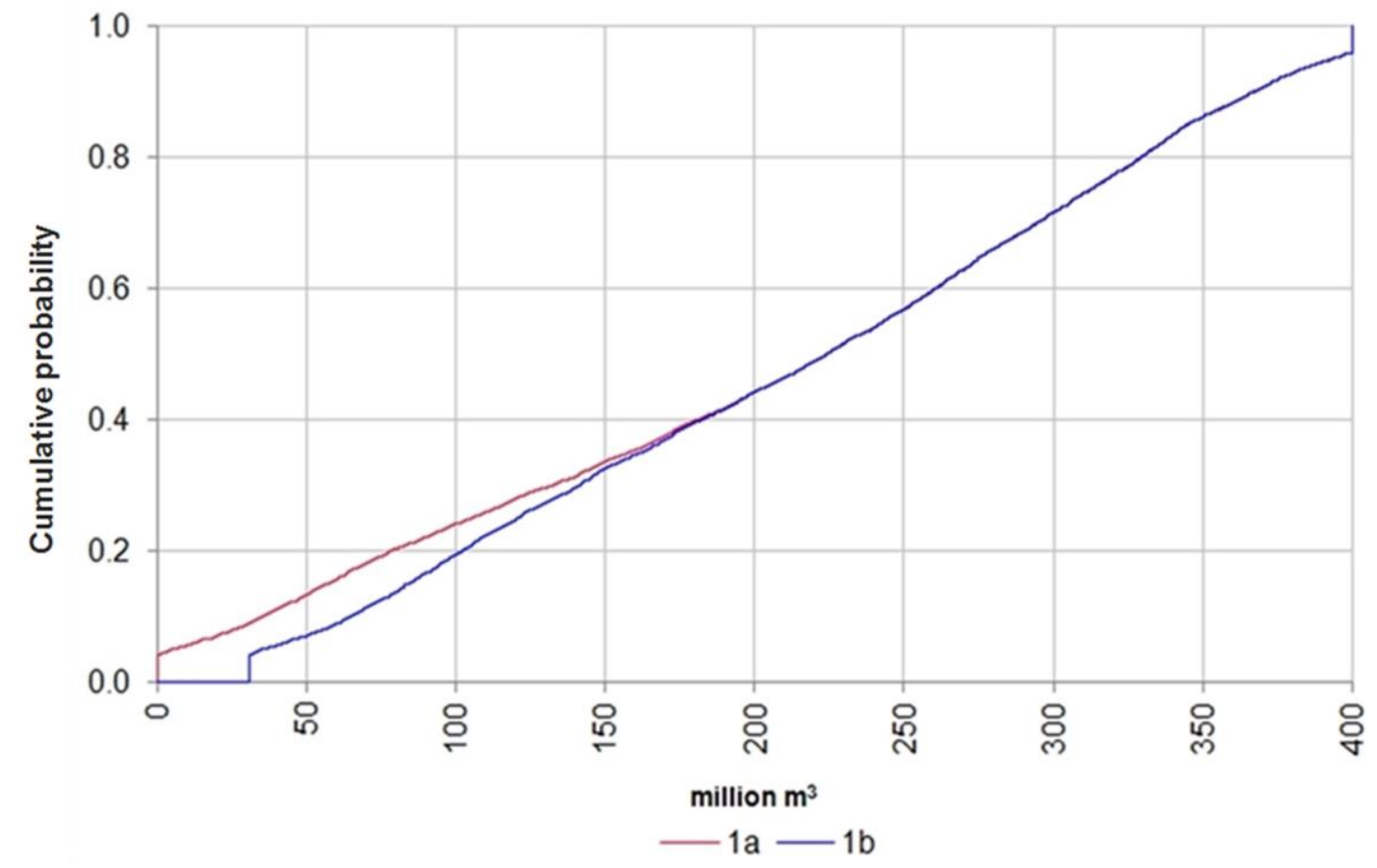

1: traditional management rule; a: no market; $b$ : with spot purchases 
Fig. 5 Cumulative probability curves representing the water availability (million $\mathrm{m}^{3}$ ) for irrigators in the Segura basin

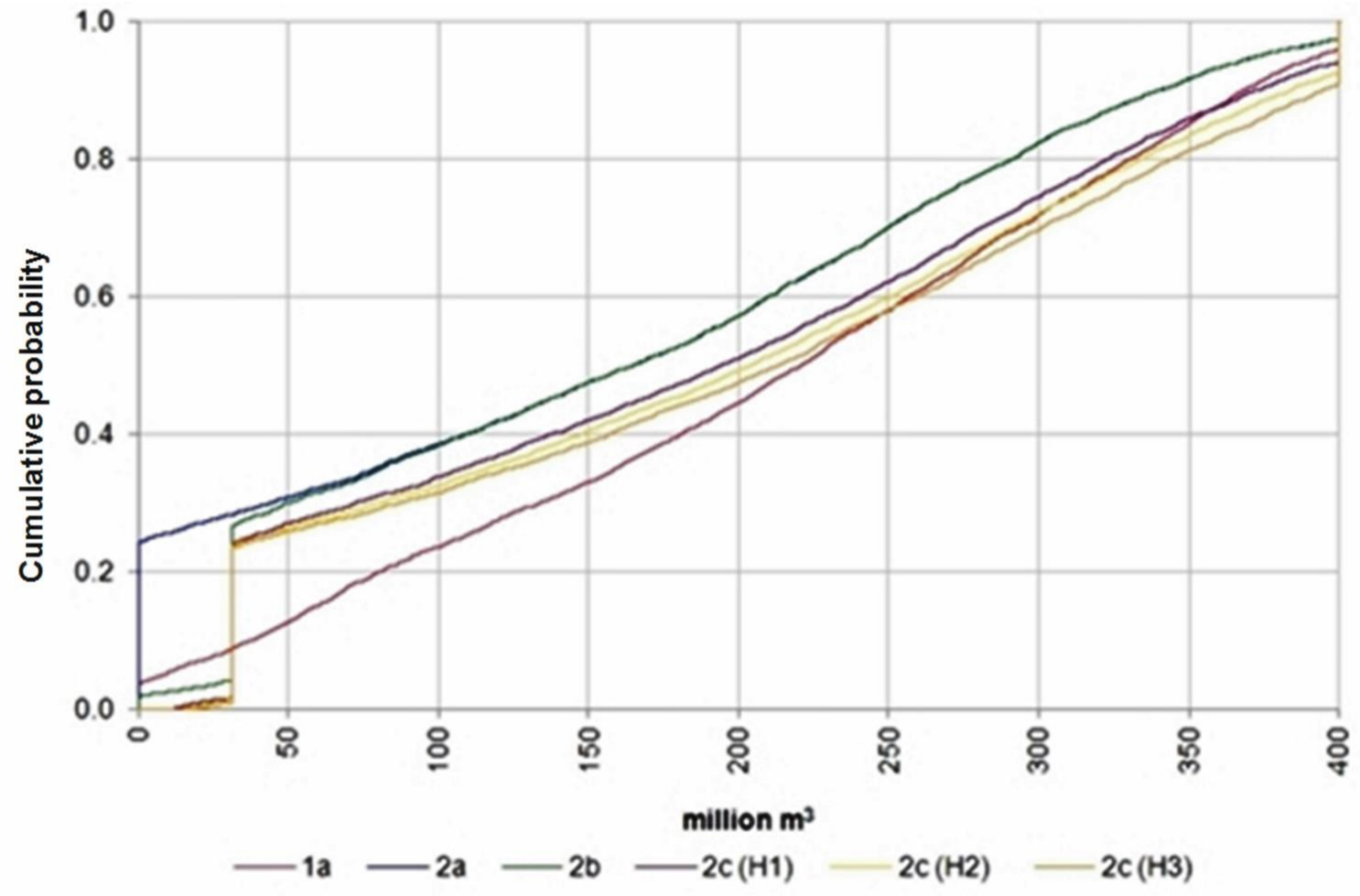

1: traditional management rule; 2 : new management rule; $a$ : no market; $b$ : with water purchases; $c$ : with the option contract. 
Fig. 6 Cumulative ascending curves of the PDFs of the remaining stock $\left(S_{e}\right)$ in E-B

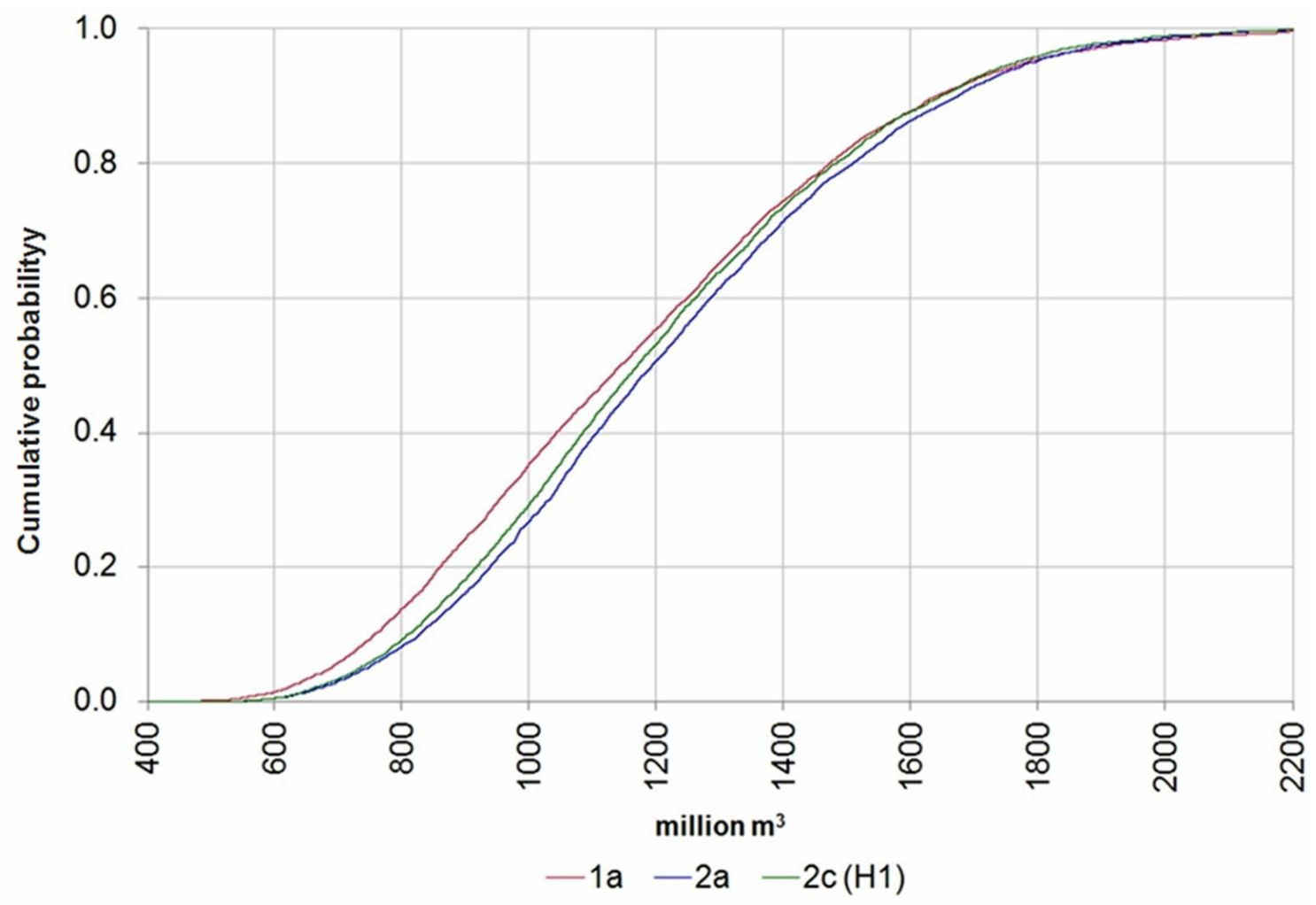

1: traditional management rule; 2 : new management rule; a: no market; c: with the option contract. 
Fig. 7 Cumulative ascending curves of PDFs of the net benefit (billion $€$ ) derived from the Tagus-Segura water transfers

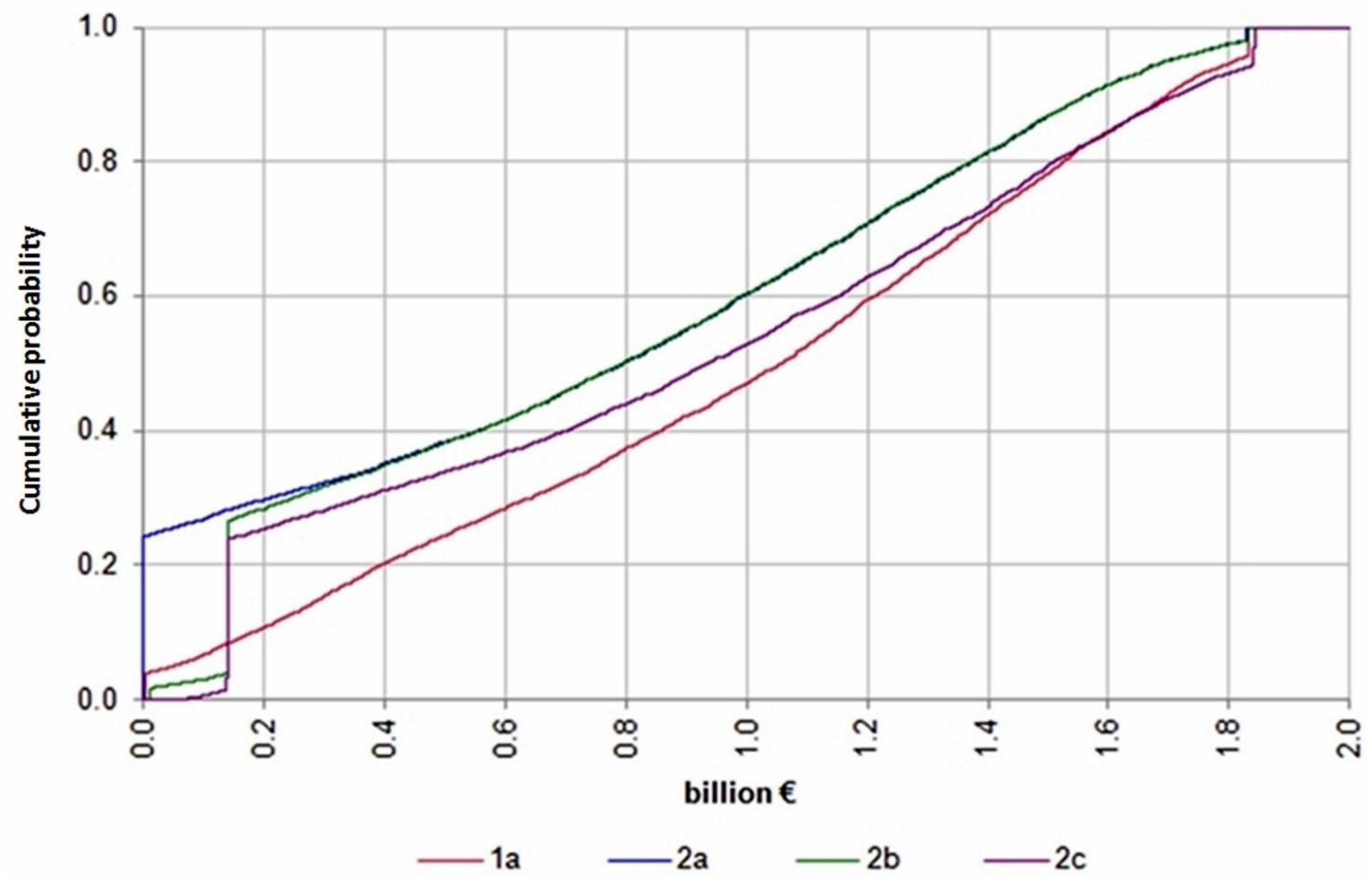

1a: traditional rule (no market); $2 \mathrm{a}$ : new rule (no market); $2 \mathrm{~b}$ : new rule (spot purchases); $2 \mathrm{c}$ : new rule (option contract, $\mathrm{H} 1)$. 
Table 1. Tagus-Segura Transfer's statutory management rules. Source: CHT (2008)

\begin{tabular}{|c|c|c|}
\hline LEVEL & RESERVOIR STATUS & $\begin{array}{c}\text { MONTHLY } \\
\text { MAXIMUM } \\
\text { TRANSFERABLE } \\
\text { VOLUME } \\
\left(\text { million } \mathrm{m}^{3}\right)\end{array}$ \\
\hline 1 & $\begin{array}{l}\text { Accumulated water inflows during the last } 12 \text { months } \\
\text { higher than } 1000 \text { million } \mathrm{m}^{3} \text {, or stored volume above } \\
1500 \text { million } \mathrm{m}^{3} \text {. }\end{array}$ & 68 \\
\hline 2 & $\begin{array}{l}\text { Accumulated inflows during the last } 12 \text { months } \\
\text { smaller than } 1000 \text { million } \mathrm{m}^{3} \text {, or tstored volume } \\
\text { below } 1500 \text { million } \mathrm{m}^{3} \text {. }\end{array}$ & 38 \\
\hline $\begin{array}{l}3 \text { (Exceptional } \\
\text { hydrological situation) }\end{array}$ & $\begin{array}{l}\text { Stored water volume lower than the volumes in Table } \\
2\end{array}$ & 23 \\
\hline $4^{\mathrm{a}}$ (No water surplus) & Stored volume below 240 million $\mathrm{m}^{3}$. & 0 \\
\hline
\end{tabular}


Table 2. Estimated regression model for the variable "annual transferred volume to irrigators" under the traditional TST management rule

\begin{tabular}{lcccc}
\hline & Coefficient & Standard error & $\mathrm{t}$ value & $\mathrm{p}$ value \\
\hline$\hat{k}$ (intercept) & -150.414 & 60.9494 & -2.47 & 0.025 \\
$\hat{a}$ (Stock) & 0.549 & 0.0592 & 9.27 & 0.000 \\
$\hat{b} \mathrm{D}$ (Stock > 1000) & -245.014 & 46.7163 & -5.24 & 0.000 \\
$\hat{c}($ Year $)$ & 26.729 & 10.5895 & 2.52 & 0.023 \\
$\hat{d}$ (Year^2) & -0.919 & 0.3766 & -2.44 & 0.027 \\
\hline Number of obs. & $20(1991-2010)$ & & & \\
$\mathrm{F}(4,16)$ & 40.08 & $\mathrm{R}^{2}$ & 0.909 & \\
Prob > F & 0.000 & Adj. $\mathrm{R}^{2}$ & 0.887 & \\
\hline
\end{tabular}


Table 3. Considered values of the $H_{i, j}$ coefficient

\begin{tabular}{ccccccccc}
\hline \multicolumn{7}{c}{ Minimum storage condition $(i)$} & Accumulated inflows $(j)$ & \\
\hline & $\mathrm{St}<550$ & $550 \leq \mathrm{St}<800$ & $800 \leq \mathrm{St} \leq 950$ & $\mathrm{St}>950$ & $\Delta I_{J-M}<350$ & $350 \leq \Delta I_{J-M} \leq 650$ & $\Delta I_{J-M}>650$ & $\mathrm{H}$ \\
interval \\
\hline $\mathrm{H} 1$ & 0 & 0.03 & 0.04 & $0.05+0.02^{\mathrm{a}}$ & $0.03^{\mathrm{a}}$ & $0.04^{\mathrm{a}}$ & $0-0.09$ \\
$\mathrm{H} 2$ & 0 & 0.04 & 0.06 & $0.07+0.02^{\mathrm{a}}$ & $0.03^{\mathrm{a}}$ & $0.05^{\mathrm{a}}$ & $0-0.12$ \\
$\mathrm{H} 3$ & 0 & 0.05 & 0.07 & $0.09+0.02^{\mathrm{a}}$ & $0.04^{\mathrm{a}}$ & $0.06^{\mathrm{a}}$ & $0-0.15$ \\
\hline
\end{tabular}

${ }^{a} 0$ if $\mathrm{St}<550$. Thus, if the stock level is below this threshold, the option holder cannot get any water volume through this part of the contract. 
Table 4. Values of the positive and negative economic factors considered for each basin and scenario

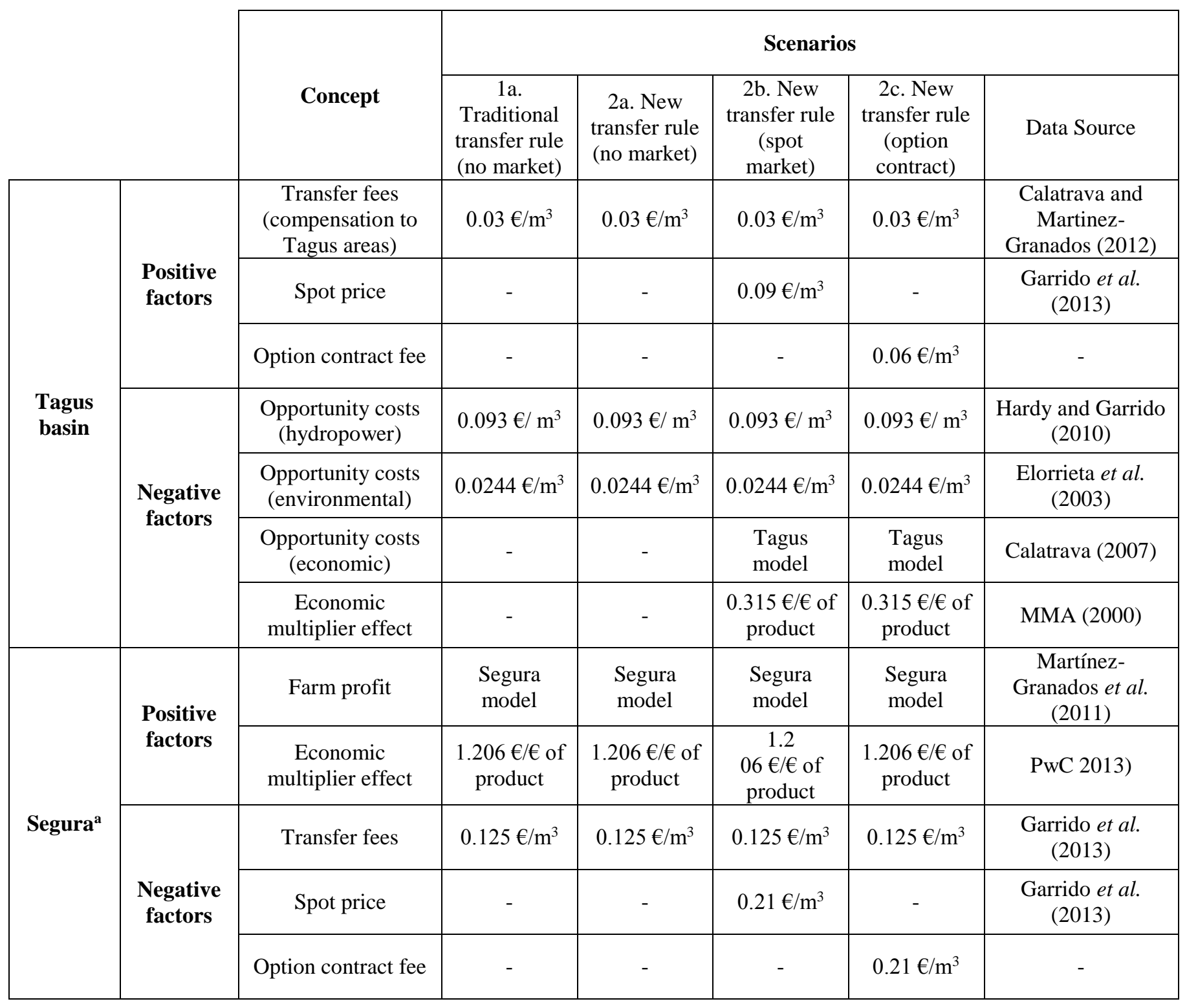


Table 5. Percentiles' value of the water availability (million $\left.\mathrm{m}^{3}\right)$, remaining stock in E-B (million $\mathrm{m}^{3}$ ) and net benefit (€ million).

\begin{tabular}{|c|c|c|c|c|c|c|c|c|c|}
\hline & Scenario & P1 & P5 & P10 & P25 & P50 & P65 & P75 & P95 \\
\hline \multirow{2}{*}{$\begin{array}{c}\text { Water } \\
\text { availability } \\
\text { in the }\end{array}$} & $1 \mathrm{a}$ & 0.00 & 6.34 & 35.50 & 105.74 & 222.14 & 274.01 & 309.42 & 398.08 \\
\hline & $2 \mathrm{a}$ & 0.00 & 0.00 & 0.00 & 6.41 & 163.76 & 231.67 & 269.83 & 371.99 \\
\hline Segura & $2 b$ & 0.00 & 31.05 & 31.05 & 31.05 & 165.03 & 230.46 & 270.26 & 372.22 \\
\hline Basin & 2c (H1) & 23.46 & 31.05 & 31.05 & 37.46 & 194.68 & 262.71 & 303.16 & 400.00 \\
\hline \multirow[t]{3}{*}{$\left(\right.$ million $\left.\mathrm{m}^{3}\right)$} & $2 \mathrm{c}(\mathrm{H} 2)$ & 29.41 & 31.05 & 31.05 & 41.26 & 204.07 & 271.10 & 313.88 & 400.00 \\
\hline & $2 \mathrm{c}(\mathrm{H} 3)$ & 31.05 & 31.05 & 31.05 & 43.09 & 213.83 & 281.77 & 325.05 & 400.00 \\
\hline & $1 \mathrm{a}$ & 577.00 & 693.97 & 764.28 & 907.02 & 1139.39 & 1295.62 & 1407.54 & 1778.93 \\
\hline \multirow{4}{*}{$\begin{array}{l}\text { Remaining } \\
\text { stock in } \\
\text { E-B } \\
\left(\text { million } \mathrm{m}^{3}\right)\end{array}$} & $2 a$ & 628.81 & 736.85 & 814.68 & 986.10 & 1198.69 & 1336.03 & 1441.40 & 1787.92 \\
\hline & $2 \mathrm{c}(\mathrm{H} 1)$ & 627.73 & 721.81 & 801.36 & 963.07 & 1175.90 & 1314.33 & 1417.11 & 1758.97 \\
\hline & $2 \mathrm{c}(\mathrm{H} 2)$ & 626.33 & 717.55 & 796.09 & 954.77 & 1168.18 & 1306.83 & 1410.41 & 1751.25 \\
\hline & $2 \mathrm{c}(\mathrm{H} 3)$ & 624.30 & 715.07 & 792.40 & 947.31 & 1161.70 & 1301.37 & 1404.75 & 1742.50 \\
\hline \multirow{4}{*}{$\begin{array}{l}\text { Net benefit } \\
\text { (€ million) }\end{array}$} & $1 \mathrm{a}$ & 6.00 & 50.81 & 180.29 & 514.61 & 1056.32 & 1290.36 & 1447.08 & 1809.58 \\
\hline & $2 \mathrm{a}$ & 2.00 & 2.00 & 2.00 & 27.70 & 797.67 & 1092.59 & 1278.04 & 1697.70 \\
\hline & $2 b$ & 10.00 & 140.05 & 141.93 & 141.93 & 795.63 & 1089.64 & 1275.39 & 1698.40 \\
\hline & 2c (H1) & 114.34 & 140.86 & 140.86 & 189.09 & 935.36 & 1245.60 & 1426.05 & 1840.93 \\
\hline
\end{tabular}

1a: traditional rule (no market); 2a: new rule (no maket); 2b: new rule (spot purchases); $2 \mathrm{c}$ : new rule (option contract). 